\title{
Triangle Strategic Management as a Pillar to Renewal Industrial Insurance and Pension Plan
}

\author{
Sunday Ade Sitorus ${ }^{1}$, Petrus Loo $^{2}$, Anto Tulim ${ }^{3}$, Suardi Yakub ${ }^{4}$ \\ ${ }^{123}$ Department of Management, STIE ITMI Medan, Komplek Asia Mega Mas Blok G No.16, Jalan Timah Putih, \\ Sukaramai II, Medan Area, Kota Medan, Sumatera Utara 20224, Indonesia \\ ${ }^{4}$ Department of System Computer, STMIK Triguna Dharma, Jl. Pintu Air I, Jend. AH Nasution No. 73, Kwala \\ Bekala, Medan Johor, Kwala Bekala, Medan Johor, Kota Medan, Sumatera Utara 20219, Indonesia
}

\begin{abstract}
The development of the insurance and pension fund management in Indonesia today, just rhetoric. Triangle Strategy Management is an alternative strategy that can be used to sustain and realize in revitalizing the administration of the insurance industry and pension funds (sustainable). Triangle strategic management as a pillar to the renewal of the insurance industry and the pension fund is a strategy to address the threat of the sustainability of the insurance industry and pension fund companies to provide protection for the customers as well as solutions that clients get out of poverty.
\end{abstract}

Keyword: Insurance, Pension Funds, Triangle Strategic Management

\section{Introduction}

When viewed from the development of the insurance and pension fund management in Indonesia today, just rhetoric. This evidenced by incomplete data on the presence of the industry and the administration of pension funds raised from the public. During this time, the paradigm in the insurance industry and pension fund management developed by the managers and all relevant elements always leads to attitudes to change the numbers and generate huge profits for the insurance company. Examine the attitude of insurance companies mentioned above; it is felt that the complexity of the problems insurance and pension fund management in Indonesia is getting complicated. The policies issued only a false policy which not all elements cannot execute it. Strategic direction is unclear and incompatible programs in the management of pension funds and the growth of the insurance industry that the community becomes not believe for her to invest their pension funds in the old days. However, if it is allowed and there are no concrete measures, the insurance industry and the management of pension funds, in particular, will be lost as a result of the greed of the owners of the insurance industry that only put self-interest and personal arrogance. The attitude that says that insurance was limited to withdraw funds when it was out of the investment must be eliminated and very hard in making an insurance fund has been invested must be removed to the insurance industry and pension funds healthy. When viewed from the many problems of the insurance, then it should be one element of the elements entrepreneurs who are always interacting with the industrial non-bank, we should be able to answer the challenge and overcome all the problems that arise in the management of the insurance industry and pension funds so as to create a pyramid of improvement insurance industry and pension funds that prioritize sustainable welfare stakeholders. Therefore, after careful examination of the above problems, the author of ideas and thoughts through this paper, titled "Triangle Strategic Management as a Pillar to Renewal Industrial Insurance and Pension Plan". This is because through the Triangle Strategic Management can provide a cooperative approach, integrated, and enthusiastic in the face of problems and opportunities and to encourage the creation of a positive attitude towards change. Performance, review, and consider the situation and make adjustments and corrections if there are irregularities in the implementation of the strategy, renewed strategy that is formulated to match an evolving external environment as well as reviewing the strengths, weaknesses, opportunities and threats businesses are constantly innovating on the product in order to always in accordance with consumer tastes.

\section{Theories}

Development of the insurance industry and pension funds on an ongoing basis is very suitable to be applied in the welfare of the shareholders, it is adapted to the conditions of the prospective customer and the owner of the insurance industry so that it appears attachment between the needy and the party needed. Therefore, in anticipation least the loss of stakeholders, desperately needed a series of strategies that can be utilized to support and revitalize the management of insurance companies and pension funds are continuing. Seen as a whole that the management and development of pension insurance in the past are still carried out conglomerate and only act on their own by the stockholders. Resulted in a shift of funds on a massive scale without the knowledge of stakeholders, which should be a major contribution to the stakeholders were not in 
line with expectations. Therefore, it should be changed thoroughly engages the whole society to act as a watchdog in the management of the insurance industry and pension funds on an ongoing basis.

From the above explanation, it could be said that the series Triangle Strategy Management is an alternative strategy that can be used to sustain and realize in revitalizing the administration of the insurance industry and pension funds (sustainable). Overall Triangle Strategy Management is a series of strategy that brings together all the elements contained in the social interaction, which binds and Strategy Management Triangle as well as to unify the circuit that had been cut off from the community, government, and entrepreneurs (investors). Through a series of Triangle Management This strategy can be seen that each element cannot hold the necessities of life without bond unites all three, so that will be formed in the implementation of the management of the insurance industry and pension funds on an ongoing basis so that the implications for improving the welfare of all stakeholders who take shelter in it. Thus, it will be delivered every desire that leads to the realization of the management of the insurance industry and pension funds on an ongoing basis. The image of the circuit elements of the Triangle Strategy Management as follows:

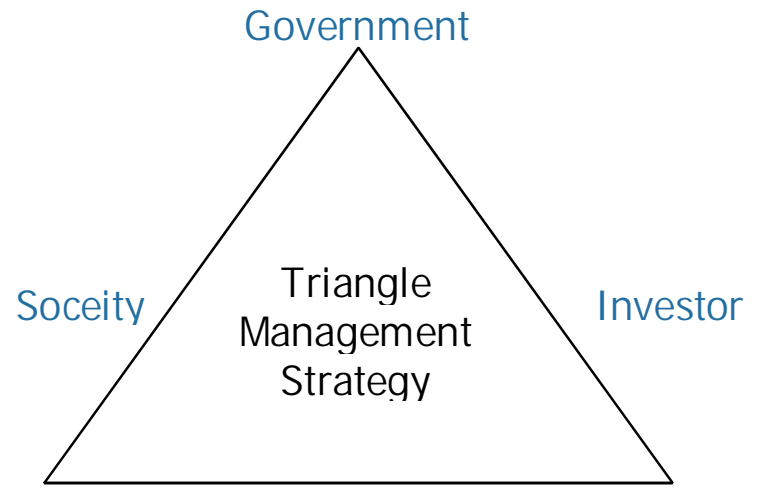

Fig 1. Triangle Management Strategy

\section{A. Triangle Policy Management Strategies}

Improving the welfare of the shareholders who put these three components business as a pillar of a holistic basis, especially in applying Triangle Management Strategy, it is because it is only through the unity of these three aspects will arise uniformity vision for management of the insurance industry and pension funds on an ongoing basis, It is not impossible, if the three component businesses already united will is reached welfare of the shareholders who will invest their funds for their future and their families. The policies implemented by Triangle Management Strategies can be combined through a bond participation thoroughly through the elements involved in the Strategic Management Triangle.

The paradigm that should be applied to all three components of the business operators should be oriented towards Helpful Management, where the implication could contribute ideas and feedback as well as sufficient data so that no data is covered to the economic welfare of the shareholder, so along with the changes that occurred then, it should be applied Triangle Strategy Management through a shared communication system between the three elements are interlinked with the surrounding. Triangle Strategy Management can be implemented through a series of strategies as follows:

1. Triangle Management Strategy Structural

Structural Triangle Strategy Management is a series of strategies that emphasize reform the system and sociopolitical and economic structures that favored the presence of three elements related to the role in the management of the insurance industry and pension funds on an ongoing basis. So as to create harmony among the three elements are related and are expected to create more opportunities to utilize, protect and preserve the development in a sustainable manner. The strategies that can be done concretely, as follows:

a. Public Accessibility Improvement Strategy, the Government, and Investors In Industry Insurance and Pension Funds

Accessibility society, governments, and investors to the data - date data is an important issue in the management of the insurance industry and pension funds on an ongoing basis. The move is expected to help people to be able to know the opportunities and the management of the insurance industry and pension funds (sustainable). The possibility in addition to improving and sustaining the economy of the shareholders is also expected to encourage people to be more active to invest their funds for a brighter future.

b. Strategy Against the Decision Making Process in the Triangle Management Strategy

Public engagement with government and investors is very necessary because it will result in policies that are tailored to the potential, aspirations and common interests. Policies based on the potential to result in increased management mutual pension fund and insurance industries in a sustainable manner. So that their efforts to 
improve the intrinsic interest of society that the welfare of the shareholders in the future. Involving together in policy making can be done with an approach that combines bottom-up and top-down planning. At the planning, level is always associated these three elements must be involved in spatial planning to absorb information and aspirations. It will be beneficial for process development zone that would serve as the archetype of the preparation of the management plan for the insurance industry and pension funds on an ongoing basis. Information and aspirations of these communities would also be useful to explore the potential of the community, especially in the management of the insurance industry and pension funds on an ongoing basis based on community. On the other hand, top-down planning is required to provide an opportunity for the government to design a pattern of management of the management area of the insurance industry and pension funds on an ongoing basis

c. Welfare-Based Monitoring System Strategy

The existence of an effective monitoring system is the main condition of the successful management of the insurance industry and pension funds on an ongoing basis. The tracking system must be able to function in a way to mobilize all relevant elements. One effective approach is the development of surveillance systems based on well-being. Surveillance systems based on well-being is a system that is guided by the interests, potential, and roles together. Therefore, monitoring systems based on the welfare in addition to providing opportunities for communities, governments, and investors to participate in supervising the management of the insurance industry and pension funds on an ongoing basis, it also strengthens a sense of community

\section{d. Development Support Network}

The development of such coordination includes the establishment of network management system can help each other. Coordination involving all relevant elements (stakeholders), a good network of government, civil society and the business world. The success of these items, in addition to technical management, will provide practical benefits, as well as socially and politically can encourage the creation of integration in the administration of the insurance industry and pension funds on an ongoing basis. To realize an efficient coordination system, it is necessary system requirements dialog between relevant agencies and between the agencies and the community. The habit of communicating ideas and action plans of each agency with other organizations is a strategic step that must be developed

\section{Triangle Strategic Management of Non - Structural}

Triangle Non-Structural Management Strategy is a series of strategies that put more emphasis on the empowerment of the pattern of the three elements. Subjective Approach Strategy (non-structural) is an approach that puts the human heart to take the initiative for the management of the insurance industry and pension funds on an ongoing basis and to increase the knowledge, skills, and awareness in the administration of the insurance industry and pension funds on a continuous basis. The strategies that can be done concretely, as follows:

a. Strategy to Increase Knowledge and Insight Industrial Insurance and Pension Funds

Awareness and insight into the management of the insurance industry and pension funds need to be promoted in a sustainable manner to provide the concept and the same view and the right to the public and investors about the management of the insurance industry and pension funds on an ongoing basis and its role in the welfare of society as a whole. This type of knowledge and insight gave settlement options vary by location and type of work. Increased awareness and insight into the management of the insurance industry and pension funds on an ongoing basis will also need all the elements involved in a series of Triangle Management Strategy

b. Skills Development Strategy

Improvement of practical expertise and management of the insurance industry in a sustainable pension fund for the public and government officials is critical to encourage the participation of these elements are actively in tackling the problems of the management of the insurance industry and pension funds on an ongoing basis would be detrimental. Such skills mainly concerned with ways of managing the insurance industry and pension funds on a continuous basis in an efficient and skills about the response to the problem

c. Community Capacity Development Strategy

Community development, government, and investors needed to be able to participate in policy-making, especially in the planning, implementation and monitoring. The main target of this program is to increase public confidence, governments and investors and the ability of initiative

d. Self Quality Development Strategy

The quality of society, governments and investors need to be improved to deal with two challenges. The first challenge is efforts to overcome the economic problems, both to overcome the issue of subsistence, and to improve the welfare wider. The second challenge is, efforts to overcome the issue of the management of the insurance industry and pension funds on an ongoing basis, that is to reduce the pressure on the administration of the insurance industry and pension funds on a continuous basis. The self-development including the development of human qualities, either individually or in groups to fill the needs of an increasingly diverse 
workforce. Program development of human qualities addition can be done through education and training as well by establishing cooperation between social institutions and economy, preparation of labor to anticipate the management activities of the insurance industry and pension funds on an ongoing basis needs to be done proactively guided by foresight front

e. Increased motivation among Government, Society and Investors To Participate

The people's desire among Government, Public and Investor should be developed to encourage their active participation in the management of the insurance industry and pension funds on an ongoing basis. To that end, efforts engagement between government, communities, and investors need to be improved continuously. Implementation needs to be integrated with those aspects that directly touches the common interest. Balancing social and economic interests have strategic significance to encourage people to get involved in the effort to manage the insurance industry and pension funds on an ongoing basis

\section{Evaluation}

From the exposure of some of the strategies contained in Triangle, Management Strategies should be complementary and can be implemented in integration. Therefore, for a complete support of a series of Strategic Management Triangle then it should be done strategy Preventive, detective and repressive. As for the strategies for sustainable development can sustain continuous insurance. Preventive strategies can be done with the following steps:

1. Strategic planning towards sustainable development in the Triangle Insurance Management Strategy

2. Improvement in the Management Control System Implementation Strategy Management Triangle

3. Improvement in providing the appropriate information in the Triangle Management Strategy

4. Improving the quality of supervision in the Triangle Management Strategy

5. Improvement in the management of the insurance industry and pension funds on an ongoing basis in the Triangle Management Strategy

Detective strategy can be done with the following steps:

1. Improvement and development of values and norms are wise in the management of the insurance industry and pension funds on an ongoing basis in the Triangle Management Strategy

2. Preparation of periodic reports on any progress in mobilizing the administration of the insurance industry and pension funds on a continuous basis in the Triangle Management Strategy

3. Conduct an inventory of all forms of completeness in the management of the insurance industry and pension funds on a continuous basis in the Triangle Management Strategy

Repressive strategies can be done with the following steps:

1. Law enforcement on the overall management of the insurance industry and pension funds on an ongoing basis in the Triangle Management Strategy

2. Increased vigilance and supervision of the administration of the insurance industry and pension funds on a continuous basis in the Triangle Management Strategy

3. Submission of accurate information to drift towards the realization of the management of the insurance industry and pension funds on a continuous basis in the Triangle Management Strategy

\section{Conclusion}

Overall of exposure that can be delivered writers to provide solutions and strategies to improve the management of the insurance industry and pension funds on an ongoing basis through the triangle strategy management in placing the administration of the insurance industry and pension funds on a continuous basis as a pillar of social welfare, it can be concluded as follows:

1. Increasing the role of the three elements incorporated in Triangle Management Strategy in enabling all power to realize the creation of the management of the insurance industry and pension funds on an ongoing basis

2. To increase the morale and conscience of every element incorporated in Triangle Management Strategies to create awareness of the importance of sound management of life insurance and pension fund industry in a sustainable manner

3. To increase the ability and skills of individuals who are members of Triangle Management Strategies to improve the welfare of the people jointly.

Of the three conclusions can I suggested, then some suggestions that can be used as a step forward in the management of the insurance industry and pension fund management on an ongoing basis through the triangle strategy, namely:

1. Increase the pattern of togetherness among each element is incorporated in Triangle Management Strategy to work together in the management of the insurance industry and pension funds on an ongoing basis 
2. The law stands for the perpetrators of the destruction, insurance, and remove the bureaucracy that ensnares each element to fight in the management of the insurance industry and pension funds on an ongoing basis.

When viewed from the exposure of the above, it is very possible to be applied in the management of the insurance industry and pension funds on an ongoing basis, so that the triangle of strategic management as a pillar to the renewal of the insurance industry and pension fund is a strategy to address the threat of the sustainability of the insurance industry and pension fund companies with providing protection for the customers as well as solutions that the clients get out of poverty.

\section{References}

[1]. Abbas Salim. 2007. Asuransi dan Manajemen Risiko. Jakarta: PT Raja Grafindo Persada

[2]. Hasyim Ali. 2003. Pengantar Asuransi. Edisi Pertama. Bumi Aksara. Indonesia.

[3]. Barney, B Jay, 2002, Gaining and Sustaining Competitive Advantage, Second Edition, Prentice Hall

[4]. Dirgantoro, Crown, 2002, Keunggulan Bersaing Melalui Proses Bisnis, PT Gramedia Widiasarana Indonesia, Jakarta

[5]. Darmawi, Herman. 2004. Manajemen Asuransi. Edisi Pertama, Cetakan Ketiga, Jakarta: PT Bumi Aksara

[6]. Edwards, R.Andres, 2005, The Sustainibilty Revolution, New Society Publishers, Canada

[7]. Kasmir. 2004. Bank dan Lembaga Keuangan Lainnya.Jakarta: PT Raja Grafindo Persada

[8]. Simorangkir, P.O. 2004. Pengantar Lembaga Keuangan Bank dan Non Bank, Bogor: Ghalia Indonesia

[9]. Porter, Michael, 1980, Competitive Strategy "Techniques For Analyzing Industries and Competitors, The Free Press,New York 